\title{
A NOTE ON THE ROLE OF EQUITY IN THE CURRICULUM OF THE MODERN LAW SCHOOL
}

\section{SHELDON TEFFT*}

One of the casualties of the generally beneficial merger of law and equity has been the abandonment by law schools of courses treating equitable relief. The author of this article perceives an increasing need for curriculum changes which will restore this neglected subject to its proper role in the education of the lawyer.

THREE-QUARTERS of a century ago Professor Frederic W. Maitland, perhaps in an attempt to discourage the students at Cambridge from attending his lectures on equity, told them that, because law and equity had been merged by the Judicature Acts of $1873^{1}$ and $1875,{ }^{2}$ the Faculty Board of that venerable university had voted to drop equity from the list of subjects which were required for its degree in law and that he approved the change:

I have no doubt however that we did the right thing. To have acknowledged the existence of equity as a system distinct from law would in my opinion have been a belated, reactionary measure. $^{3}$

Though Professor Maitland continued to lecture on equity until his untimely death in 1906 and though shortly thereafter his lectures were published by the Cambridge University Press, ${ }^{4}$ equity did not have a place as a separate subject at Cambridge until 1962 when its Faculty Board re-introduced a paper on equity as an option in the newly-revised Cambridge curriculum in law..$^{5}$

In contrast, the Law Faculty at Oxford, perhaps as a belated effort

A.B. 1922, LL.B. 1924, University of Nebraska; B.A. in Jurisprudence 1926, B.C.I. 1927, M.A. 1930, Oxford University. James Parker Hall Professor of Law, The University of Chicago Law School.

1 The Supreme Court of Judicature Act, $1875,36 \& 37$ Vict. c. 66.

2 The Supreme Court of Judicature Act, 1875, 38 \& 39 Vict. c. 77.

- Maitland, Equity 21 (1909).

- Martzand, Equitry (1909).

- See Dias, The New Cambridge LLB. Examination, 7 J. Soc'y PuB. Teachers L. 16, 18 (1962); Dias, The New Cambridge Tripos, 6 J. Soc'Y PuB. Tenchers L. 80, 84 (1961). 
to atone for the failure of its first Vinerian Professor, Sir William Blackstone, to have done justice to equity ${ }^{\bullet}$ or perhaps only because of its traditional policy of embracing lost causes, continued even after the Judicature Acts to include, and indeed still does include, equity as one of the subjects that are required for the degree of Bachelor of Civil Law. ${ }^{7}$ Sir William S. Holdsworth, the Vinerian Professor from 1922 to 1944 , and Professor Harold G. Hanbury, ${ }^{8}$ who held the chair from 1949 to 1964, were enthusiastic exponents of separate courses in equity. Sir William detested the attempt to teach equity in snippets. ${ }^{9}$ In a survey for the golden jubilee of the Law Quarterly Review he reported, apparently with great satisfaction, that in England during the preceding fifty years the study of equity had flourished and concluded his contribution with the sentiment: "May it continue to flourish."10

In the United States more than sixty years ago Dean Roscoe Pound of the University of Nebraska warned the Bar that because of the merger of law and equity under the codes there was grave danger that, unless lawyers were vigilant, much equity would be lost. ${ }^{11}$ In a stirring and yet scholarly paper presented to the Association of American Law Schools in 1933, Professor Percy Bordwell of Iowa called upon the faculties of American Law Schools to take the offensive and fight for equity-not to restore the conditions of the past-not to campaign for separate courts with separate procedures, or even for separate courses, but rather for a militant equity-one that would protect the ethical tone, characteristic of equity at its best, and thus would preserve its historic role as the forward element of the Anglo-American legal system. ${ }^{12}$

But what are those fundamental institutions which must be nurtured and sheltered if the historic role of equity is to be pre-

\footnotetext{
- See Holdsworth, Blackstone's Treatment of Equity, 43 HaRv. L. REv. 1 (1929).

'See Harris, Changes in the B.C.L. Syllabus at Oxford, 6 J. Soc'y PUB. TeAchers L. 121-22 (1961).

- See Hanbury, Essays in Equity 55-68 (1934); Hanbury, Modern Equity (8th ed. 1962) (first edition published in 1935).

- Holdsworth, Equity, 51 L.Q. REv. 142, 161 (1935).

10 Ibid.

11 Pound, The Decadence of Equity, 5 Colum. L. REv. 20 (1905). See also THE Federalist No. 83, at 528-29 (Lodge ed. 1911) (Hamilton).

12 Bordwell, The Resurgance of Equity, 1 U. CHI. L. REv. 741 (1934). See also Cook, The Place of Equity in Our Legal System 77 (Proceedings, Twelfth Annual Meeting, Ass'n of Am. Law Schools, 1912); McCuINTOck, EQurTY 18-19 (1936); Orfield, The Place of Equity in the Law School Curriculum, 2 J. Legal Ed. 26 (1949).
} 
served? When Anglo-American lawyers think of equity they are likely to think of institutions of substantive law, such as the trust, the equity of redemption, and the restrictive covenant created by the chancellors with little or no help from legislatures and by means of which large and important segments of the Anglo-American legal system have been revolutionized. But valuable as equity's contributions to substantive law have been, they are dwarfed in importance, either from the point of view of legal theory, or from the point of view of the practical affairs of the modern world by the all-pervasive principle of the chancellor that specific relief should be decreed in any case in which the court is persuaded that such relief is feasible and that it is both important and "equitable" that such relief be available. To make this principle effective, the chancellor had devised the decree in personam-an order to which the Great Seal was attached-directing a party either to act or to refrain from acting, or both, as the "equities" of the situation required. It is this device -the decree in personam, drafted to fit the particular case and made effective by the threat that one who disobeys it will be punished for contempt of court-rather than rules of substantive law, that constitutes the really important contribution of equity to the AngloAmerican legal system.

Fortunately, the abolition of the separate courts of law and equity and the adoption of a unified procedure did not and were not intended either to curb or to abolish the power of courts to afford specific relief. Rather, the principle that society should and will afford such relief flourishes in the United States today as never before in the history of the Anglo-American legal system. ${ }^{13}$ Indeed, perhaps the most important development in the law of the United States during the two decades of the atomic age has been the remarkable extension of specific relief-to be achieved by decrees in personam-for the protection of individuals and society from threatened conduct that is deemed to be unlawful. ${ }^{14}$

During this period there has been a tremendous and at times

\footnotetext{
13 Compare, however, statutes such as the Norris-La Guardia Act $\$ \$ 1-15,47$ Stat. 70 (1932), 29 U.S.C. $\$ \S 101-115$ (1964), and decisions such as Shelley v. Kraemer, 334 U.S. 1 (1948).

${ }^{14}$ See, e.g., Hughley v. City of Opelika, 251 F. Supp. 566, 569 (M.D. Ala. 1965); Hurwitt v. City of Oakland, 247 F. Supp. 995, 1006-09 (N.D. Cal. 1965); McMeans v. Mayor's Court, 247 F. Supp. 606, 610 (M.D. Ala. 1965); Williams v. Wallace, 240 F. Supp. 100, 110 (M.D. Ala. 1965) (Selma March Case). For additional illustrations see notes $16-24$ infra.
} 
an almost overwhelming surge of specific relief. Many of the classic restrictions that had limited the availability of such relief fairly narrowly have been cast aside-perhaps, as some believe, too many by far. ${ }^{15}$ The particulars of this surge are numerous, varied, and striking. They include developments as diverse as the doctrine of the "void but non-frivolous decree,"16 the Uniform Commercial Code, ${ }^{17}$ and the so-called "Long Arm Statutes"; 18 and as far reaching as the segregation cases, ${ }^{10}$ the Civil Rights Acts of $1957,{ }^{20} 1960,{ }^{21}$ and $1964,{ }^{22}$ the Voting Rights Act of $1965,{ }^{23}$ the reapportionment cases, ${ }^{24}$ and many more. Though specific relief has not displaced and, of course, never will displace judgments for damages, decrees in personam are no longer confined to a relatively few branches of the legal system that tend to be the province of a small group of experts who specialize in chancery matters.

If the challenges of the space age are to be met and if the objectives highly valued in society today are to be attained, lawyers generally, as well as those who specialize in chancery matters, must have a thorough, enlightened knowledge of the remedy of specific relief, achieved through decrees in personam, as an instrument for the administration of justice. It is imperative, therefore, that the program of the modern law school include a comprehensive study of the procedures by which judicial power may be used to afford

${ }^{16}$ See, e.g., Reynolds v. Sims, 377 U.S. 533, 589.632 (1964) (Harlan, J., dissenting); Baker v. Carr, 369 U.S. 186, 266-330 (1962) (Frankfurter, J., dissenting); id. at 330-49 (Harlan, J., dissenting); Neal, Baker v. Carr: Politics in Search of Law, 1962 Sup. CT. REV. 252; BICKel, Politics AND THE WARREN CoURT (1965); Kurland, "Equal in Origin and Equal in Title to the Legislative and Executive Branches of the Government," 78 HARv. L. REv. 143 (1964); Note, 65 Mich. L. REv. 556 (1967) (noting Lance v. Plummer, 353 F.2d 585 (5th Cir. 1965), cert. denied, 384 U.S. 929 (1966)). Compare Stevens, A Plea for the Extension of Equitable Principles and Remedies, 41 CORNELI L.Q. 351 (1956).

10 See Cox, The Void Order and the Duty to Obey, 16 U. CHI. L. REv. 86 (1948).

17 UNIFORM COMMIERCIAL CODE § 2-716.

${ }^{18}$ Currie, The Growth of the Long Arm: Eight Years of Extended Jurisdiction in Illinois, 1963 U. ILL. L.F. 533.

${ }^{19}$ Burton v. Wilmington Parking Authority, 365 U.S. 715 (1961); Brown v. Board of Educ., 349 U.S. 294 (1955); United States v. Jefferson County Bd. of Educ., 372 F.2d 836 (5th Cir. 1966); New Orleans City Park Improvement Ass'n v. Detiege, 252 F.2d 122 (5th Cir.), aff'd, 358 U.S. 54 (1958).

2071 Stat. 634 (codified in scattered sections of 5, 28, 42 U.S.C. (1964)).

2174 Stat. 86 (codified in scattered sections of 18, 20, 42 U.S.C. (1964)).

2278 Stat. 241 (codified in scattered sections of 5, 28, 42 U.S.C. (1964)).

2379 Stat. 437, 42 U.S.C. $\$ \S 1973$, 1973a-p (Supp. I, 1965).

${ }^{26}$ E.g., Lucas v. Forty-Fourth Gen. Assembly, 377 U.S. 713 (1964); Reynolds v. Sims, 377 U.S. 533 (1964); Gray v. Sanders, 372 U.S. 368 (1963); Baker v. Carr, 369 U.S. 186 (1962). 
specific relief. With few exceptions ${ }^{25}$ those procedures were developed by courts of equity and, even under modern codes, are commonly described as equitable. The effectiveness of that remedy depends primarily upon the "equitable" characteristics of those procedures-their flexibility and speed and the opportunity that they afford for the exercise of judicial discretion to mould the proceedings to fit the peculiar requirements of individual cases. ${ }^{26}$

Such study, if it is to be adequate, must illuminate the role of specific relief not only in the traditional fields of contracts and property, but also in many other branches of the law including, of course, those of constitutional and criminal law. It must encompass interlocutory relief as well as relief that is granted after a trial on the merits. The study should show how specific relief can be enforced not only in the simple vendor-purchaser cases, but also in the more difficult situations such as those in which performance extending over a period of time will be required, ${ }^{27}$ or in which the line that separates activity which is lawful from that which is unlawful is difficult to determine and is, at best, vague and imprecise. ${ }^{28}$ It should explain the technique of the "experimental" decree ${ }^{29}$ and the power that courts have either to modify or to dissolve a decree-whether temporary or permanent-in the light of experience gained from "living with the decree" or of changes which have occurred since the decree was issued. ${ }^{30}$ It is important, too, that such factors as mistake, hardship, fairness, "clean hands," laches, and "equitable terms" not be slighted.

Moreover, since specific relief is now undertaken in many controversies that are highly charged with emotions, the difficult prob-

\footnotetext{
${ }^{25}$ The principal exception is ejectment.

${ }^{28}$ Stone, Book Review, 18 Convm. L. Rrv. 97 (1918). See Bereslavsky v. Caffey, 161 F.2d 499, 500 (1947) (Frank, J.).

${ }^{27}$ See Wisconsin v. Illinois, 278 U.S. 367 (1929). Subsequent Supreme Court con. siderations of the dispute, which is still pending, appear at 281 U.S. 179 (1980), 281 U.S. 696 (1930), 309 U.S. 569 (1940), 309 U.S. 636 (1940), 811 U.S. 107 (1940), 313 U.S. 547 (1941), 385 U.S. 996 (1967).

${ }^{28}$ See, e.g., Gelfand v. O'Haver, 33 Cal. 2d 218, 200 P.2d 790 (1948); Five Oaks Corp. v. Gathmann, 190 Md. 348, 58 A.2d 656 (1948); Washington Cleaners \& Dyers, Inc. v. Albrecht, I57 Md. 389, 146 Atl. 233 (1929).

${ }^{22}$ See, e.g., Wisconsin v. Illinois, 278 U.S. 367 (1929) (subsequent history traced in note 27 supra); Georgia v. Tennessee Copper Co., 206 U.S. 230 (1907), 237 U.S. 678 (1915), 237 U.S. 474 (1915), 240 U.S. 650 (1916).

${ }^{30}$ See Lowe v. Prospect Hill Cemetery Ass'n, 75 Neb. 85, 106 N.W. 429 (1905), aff'd on rehearing, 75 Neb. 100, 108 N.W. 978 (1906); Ladner v. Siegel, 298 Pa. 487, 148 Atl. 699 (1930).
} 
lems encountered when a recalcitrant defendant flaunts a decree of specific relief must be stressed. ${ }^{31}$ All in all, the problems would seem to be sufficiently numerous, challenging, and important to justify separate coherent and comprehensive treatment. ${ }^{32}$ Whether the vehicle for such treatment is a course entitled "equity" is relatively unimportant. Conceivably, some may wish to fit the study into a general course on procedure. Perhaps the place of the study in a particular school will reflect the idiosyncrasies of its faculty. Such matters are, of themselves, insignificant details. What is important is that the students master specific relief as a remedy for the protection of individuals and society from theatened conduct which is unlawful. For only if this is done can they be prepared for the challenges of the space age. And so it is that the sentiment of the author of The Practical Register in Chancery that "justice and equity, and the lovers of them, may forever flourish" 33 is as appropriate today as it was in 1935 for the Law Quarterly Review's golden jubilee $e^{34}$ or in 1714 when the Register was first published.

${ }^{32}$ See Jencks v. Goforth, 57 N.M. 627, 261 P.2d 655 (1953); New Jersey Zinc Co. v. Local 890, International Union of Mine Workers, 57 N.M. 617, 261 P.2d 648 (1953); Jamur Prods. Corp. v. Quill, 51 Misc. 2d 501, 273 N.Y.S.2d 348 (Sup. Ct. 1966); Weinstein v. New York City Transit Authority, 49 Misc. 2d 170, 267 N.Y.S.2d 111 (Sup. Ct. 1966); Manhattan \& Bronx Surface Transit Operating Authority v. Quill, 48 Misc. 2d 1021, 266 N.Y.S.2d 423 (Sup. Ct. 1966); New York City Transit Auathority v. Quill, 48 Misc 2d 940, 266 N.Y.S.2d 296 (Sup. Ct. 1965); Re Tilco Plastics Ltd. v. Skurjat, [1966] 2 Ont. 547, 57 D.L.R.2d 596 (1966); Canadian Transp. (U.K.) Ltd. v. Alsbury, [1952] 6 West. Weekly R. (n.s.) 473 (B.C. Sup. Ct.), appeal dismissed, [1952-1953] 7 West. Weekly R. (n.s.) 49, [1953] 1 D.L.R. 385 (B.C. Ct. App. 1952), appeal dismissed sub nom. Poje v. Attorney Gen., [1953] 1 Can. Sup. Ct. 516, [1953] 2 D.L.R. 785; CarRothers, A STUDY OF THE OPERATION OF THE INJUNCTION IN LABOUR-MANAGEMENT DisPUTES IN BRITISH Columbia, 1946.1955 (1956); ONTARIo DeP'T OF LABOUR, REPORT OF A StUdy ON THE Labour INJUNCTION IN ONTARIo (Carrothers ed. 1966).

${ }^{32}$ See Stevens, A Brief on Behalf of a Course in Equity, 8 J. LEGAL ED. 422 (1956). Compare, however, Sedler, Equitable Relief But Not Equity, 15 J. LEGAL ED. 293 (1963).

as The Practical Register in Chancery v, viii (Wyatt ed. 1800).

see supra note 9. 